\title{
Growth and survival of cryopreserved oyster and clam larvae along a pollution gradient in the German Bight
}

\author{
I. R. B. McFadzen \\ Natural Environment Research Council, Plymouth Marine Laboratory, Prospect Place, West Hoe, Plymouth, \\ Devon PL1 3DH, United Kingdom
}

\begin{abstract}
The effects of contaminants along a well-defined North Sea pollution gradient were assessed during the Bremerhaven Workshop using cryopreserved veliger larvae of the Pacific oyster Crassostrea gigas and the Manila clam Tapes philippinarum. The results demonstrate that larval survival steadily improves as the transect moves offshore towards the Dogger Bank, with higher mortalities occurring in the surface microlayer and sediment elutriate samples than in the subsurface bulk waters. Clam larvae were more sensitive to contaminants and natural food availability than the younger oyster larvae. The results from survival and growth data also discriminate between 2 dominant local water masses traversed by the transect.
\end{abstract}

\section{INTRODUCTION}

Water quality bioassays, utilising the pelagic stages of several taxa of marine invertebrates, have been routinely used to monitor the integrated biological effects of contaminants and the variables that influence their toxicity in sea water (Stebbing 1985). Since the early experiments by Wilson (1951) and Wilson \& Armstrong (1961) who identified different water masses based on the development of larval echinoderms and polychaetes, several researchers (Woelke 1967, 1972, Kobayashi 1971, Connor 1972) have used embryonic and larval stages of many species to assess water quality. Kobayashi (1971) used 3 species of echinoderm with different reproductive seasons in order to provide larvae for bioassays over the whole year, whilst Stebbing \& Pomroy (1978) overcame reproductive seasonality of test organisms with laboratory cultures of cloned hydroids.

Cryopreservation techniques eliminate reproductive seasonality, minimise genetic heterogeneity between tests and maintain viable veliger larvae over indefinite time periods. The benefits of this technique have been demonstrated in commercial hatcheries (Utting \&
McFadzen 1990). The aim of this investigation was to apply this technique to environmental monitoring programmes and to assess the growth and survival of larvae that had been cryopreserved, when exposed to environmental xenobiotics.

The workshop held in Bremerhaven in 1990 gave an unprecedented opportunity to test the field validation of cryopreserved bivalve larvae deployed at sea for use as a field monitoring water quality bioassay. The aim of this investigation was to compare the findings with those obtained simultaneously with similar bioassays, from the same sample stations along a contaminant gradient (Karbe 1992).

\section{MATERIAL AND METHODS}

Larval culture. Adult broodstock conditioning and larval rearing of the Pacific oyster Crassostera gigas and the Manila clam Tapes philippinarum were conducted at the Ministry of Agriculture, Fisheries and Food (MAFF) Fisheries Laboratory, Conwy (Utting \& Spencer 1991). Viable gametes from 3 males and 3 females were pooled for each species. Oyster larvae 
were reared for $24 \mathrm{~h}$ post-fertilisation and cryopreserved before the onset of exogenous feeding. Clam larvae were reared for $48 \mathrm{~h}$ post-fertilisation feeding on a mixed diet of Chaetoceros calcitrans, Isochrysis galbana and Tetraselmis suecica during the latter $24 \mathrm{~h}$ period, prior to cryopreservation.

Cryopreservation and larval storage. Recently developed proprietary freezing and thawing techniques were used. The methodologies for these are described in PCT Published Patent Application No. WO 91/91636, published 21 February 1991. Larvae of each species were cryopreserved en masse in a single freezing protocol in multiple $0.5 \mathrm{ml}$ plastic straws and stored under liquid nitrogen $\left(-196^{\circ} \mathrm{C}\right)$ for $3 \mathrm{~d}$. Frozen straws of larvae were transferred to pre-cooled $\left(-150^{\circ} \mathrm{C}\right)$ dry shippers for transportation to the workshop. Larvae were maintained at temperatures below $-150^{\circ} \mathrm{C}$ for between 5 and $10 \mathrm{~d}$ until thawed for use in the bioassay aboard the RV 'Valdivia'.

Sampling. Sampling methods and station samples are given in Karbe (1992). The choice and location of the transect together with station locations are given by Stebbing \& Dethlefsen (1992). Stn 0, used as a
Table 1 Larval viability and number recovered from each straw assessed 30 min post-thaw. Mean \pm SD based upon 3 straws per batch. Initial length measurements are given (mean \pm SD) for each species 30 min post-thaw, $\mathrm{n}=50$. Oyster larvae were cryopreserved $24 \mathrm{~h}$ post-fertilisation and clam larvae $48 \mathrm{~h}$ post-fertilisation

\begin{tabular}{|lccc|}
\hline & $\begin{array}{c}\% \text { Viability } \\
\text { per straw }\end{array}$ & $\begin{array}{c}\text { No. recovered } \\
\text { per straw }\end{array}$ & $\begin{array}{c}\text { Initial length } \\
(\mu \mathrm{m})\end{array}$ \\
\hline $\begin{array}{l}\text { Batch 1 } \\
\text { Oyster }\end{array}$ & $97.1 \pm 1.0$ & $1845 \pm 13.2$ & $71 \quad \pm 2.04$ \\
Clam & $97.3 \pm 1.53$ & $1036 \pm 18.7$ & $86.44 \pm 2.88$ \\
Batch 2 & & & \\
Oyster & $97.0 \pm 1.73$ & $1860 \pm 20.1$ & $70.11 \pm 2.34$ \\
Clam & $96.67 \pm 2.08$ & $1240 \pm 23.7$ & $85.65 \pm 3.01$ \\
\hline
\end{tabular}

'shakedown' station by the Water Quality Bioassay Group, lies just off Helgoland in the German Bight (Karbe 1992).

The bioassay technique. Three straws of each species were thawed individually (to a temperature of 20 to $22^{\circ} \mathrm{C}$ ), then pooled in 'clean' reference sea water (Burnham-on-Crouch [UK] winter water provided by
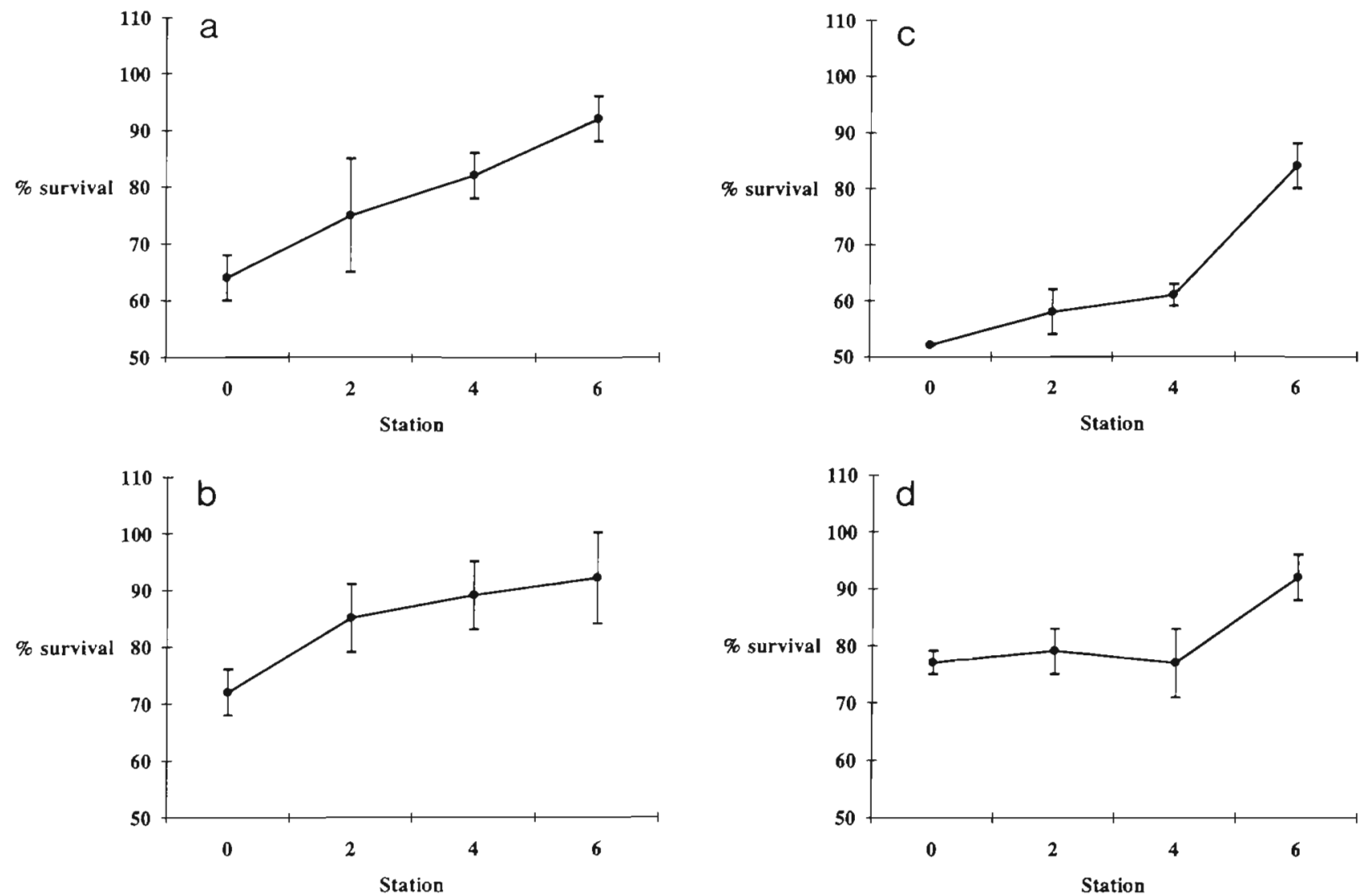

Fig. 1. Percentage survival of larvae following 48 h exposure (mean \pm 2 SE). Mean based on 2 replicate subsamples. (a) Crassostrea gigas (age 24 to $72 \mathrm{~h}$ ) microlayer; (b) C. gigas $0.5 \mathrm{~m}$ subsurface water (c) Tapes philippinarum (age 48 to $96 \mathrm{~h}$ ) microlayer; (d) T. philippinarum $0.5 \mathrm{~m}$ subsurface water 

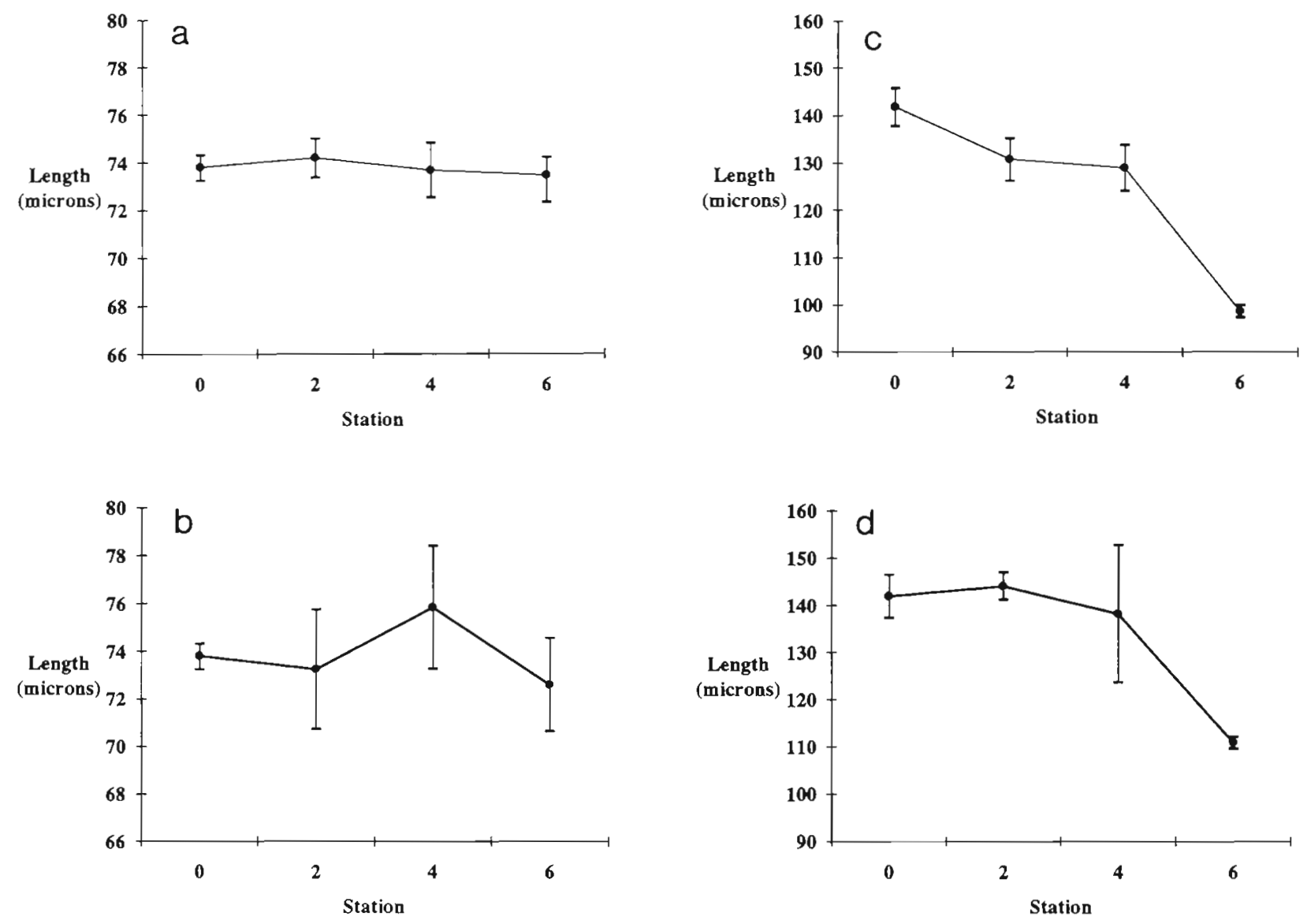

Fig. 2. Maximum shell length in $\mu \mathrm{m}$ (mean $\pm 2 \mathrm{SE}$ ). Mean based on total number of viable larvae from 2 replicate subsamples. (a) Crassostrea gigas microlayer; (b) C. gigas 0.5 m subsurface water; (c) Tapes philippinarum micro-layer; (d) T. philippinarum $0.5 \mathrm{~m}$ subsurface water

J. Thain, MAFFJ to reduce any possible interstraw variability. Larval viability and numbers recovered from straws were assessed $30 \mathrm{~min}$ post-thaw (Table 1) before exposure to the sample.

Table 2. Samples taken and station number. Numbers 1 and 2 denote larval thawing batch used on that sample (see Table1); 0 represents no sample taken

\begin{tabular}{|ccccc|}
\hline Stn & \multicolumn{4}{c|}{ Sample } \\
& Microlayer & $0.5 \mathrm{~m}$ & $3.0 \mathrm{~m}$ & Sediment \\
subsurface subsurface & elutriate \\
\hline 0 & 1 & 1 & 0 & 0 \\
1 & 0 & 0 & 1 & 1 \\
2 & 1 & 1 & 1 & 1 \\
3 & 0 & 0 & 1 & 1 \\
4 & 1 & 1 & 1 & 1 \\
5 & 0 & 0 & 1 & 1 \\
6 & 2 & 2 & 2 & 2 \\
7 & 0 & 0 & 2 & 2 \\
8 & 0 & 0 & 2 & 2 \\
9 & 0 & 0 & 2 & 2 \\
\hline
\end{tabular}

Approximately 300 larvae were concentrated into a minimum volume of reference sea water on a $45 \mu \mathrm{m}$ nytex mesh. Larvae were then carefully rinsed with a small volume of test water, before decanting into duplicate (subsample) $30 \mathrm{ml}$ glass vials (10 larvae $\mathrm{ml}^{-1}$ ) containing the sample sea water. All vials of sample water were spiked with $100 \mu$ l of Isochrysis galbana to provide a minimum algal ration for the exposure period (Utting \& Spencer 1991). Sample water was then equilibrated to the incubation temperature $\left(20^{\circ} \mathrm{C}\right)$ prior to the addition of the larvae.

All samples were maintained under static conditions and stored at $20^{\circ} \mathrm{C}$ for $48 \mathrm{~h}$. Each vial was then treated with $4 \%$ buffered formalin to preserve the larvae for subsequent analysis. This was repeated aboard the RV 'Valdivia' when sufficient water samples had been taken to conduct a bioassay (Table 2).

Microscopic examination of larvae was conducted at random with survival assessed as the number of viable larvae observed in the first 50 larvae encountered. Initial length measurements of viable larvae were made at the workshop, using a graticule eye piece 

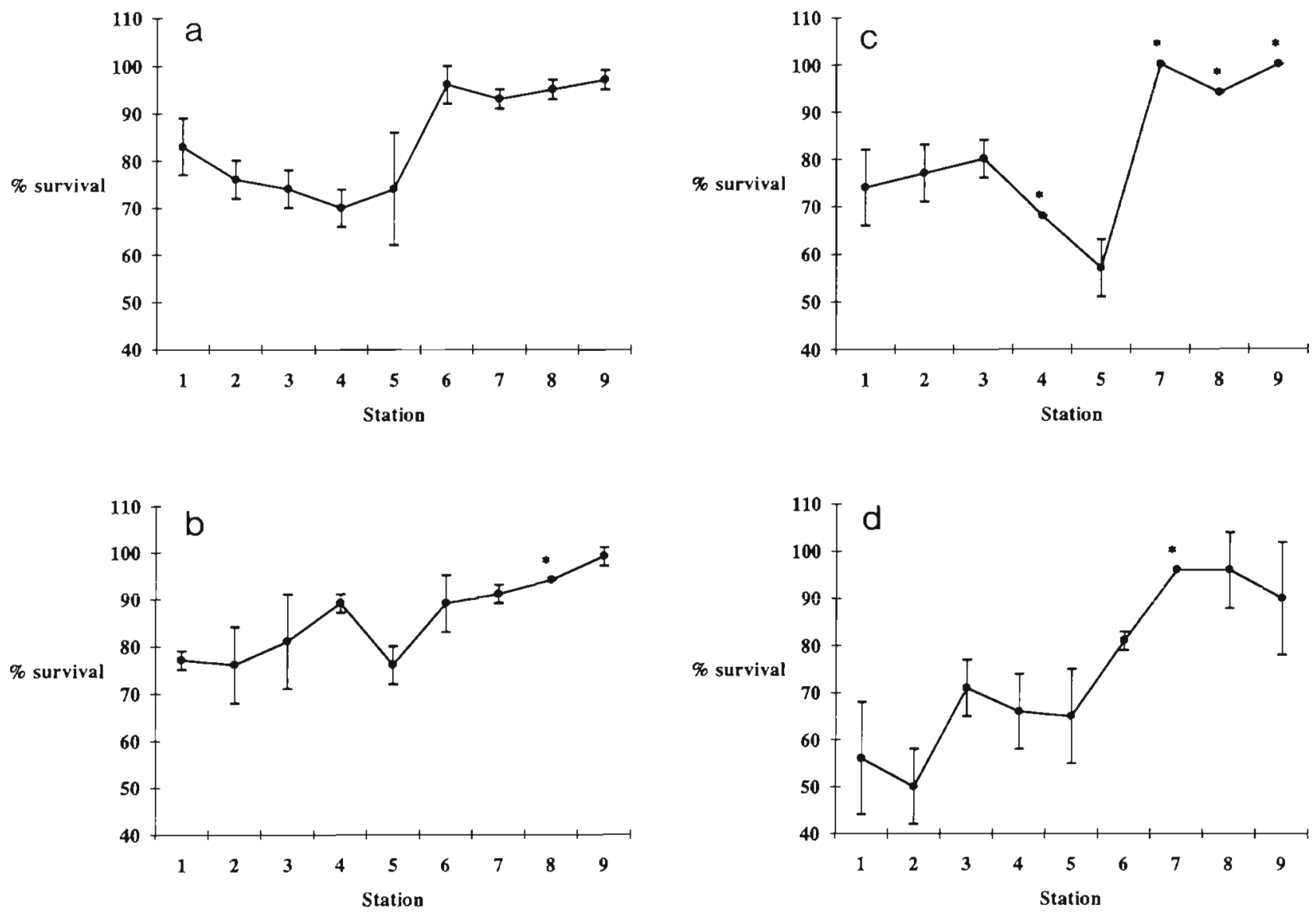

Fig. 3. Percentage survival of larvae (mean $\pm 2 \mathrm{SE}$ ). Mean based on 2 replicate subsamples; indicates a single sample. (a) Crassostrea gigas $3.0 \mathrm{~m}$ subsurface water; (b) C. gigas sediment elutriate; (c) Tapes philippinarum $3.0 \mathrm{~m}$ subsurface water; (d) $T$. philippinarum sediment elutriate

fitted to a Leitz compound microscope (Table 1). Subsequent semi-automated analysis of larvae was carried out using a Kontron IPS image analyser, linked to a Reichert Polyvar microscope, measuring maximum length parallel to the valve hinge.

\section{RESULTS}

The cryopreservation technique utilised for this bioassay gave high larval viability upon thawing from the ultra-low storage temperatures (Table 1). Samples taken at each station and larval batch used are given in Table 2.

\section{Surface microlayer and $0.5 \mathrm{~m}$ subsurface bulk water}

Survival. The survival of oyster and clam larvae steadily improved as the transect moved offshore from the mouths of the rivers Elbe and Weser, towards the Dogger Bank (Fig. 1) with significantly lower clam survival in the microlayer than in the subsurface
$0.5 \mathrm{~m}$ bulk water (Fig. 1c, d). Oysters showed no significant differences in survival (Fig. 1a, b) between microlayer and bulk waters, but the overall trend was lower in the microlayer. No differences in survival between species were observed in the bulk water Fig. 1b, d), however clam larvae had higher mortalities in the microlayer than the oysters for all stations (Fig. 1a, c)

Length. Clam larvae grew significantly more in the inshore stations $(0,2 \& 4)$ compared to Stn 6 (Fig. 2a, b) for microlayer and bulk waters. However, larvae in the bulk water were larger than those exposed to the microlayer at Stns 2, $4 \& 6$ (Fig, 2a, b). Oysters did not show any length differences either between stations or sample types (Fig. 2c, d) with bulk water larvae having a greater variability in length.

\section{$3.0 \mathrm{~m}$ subsurface water and sediment elutriate}

Survival. The survival of both species improved markedly as the transect moved offshore (Fig. 3) with significantly higher survival in bulk waters from Stns 6 to 

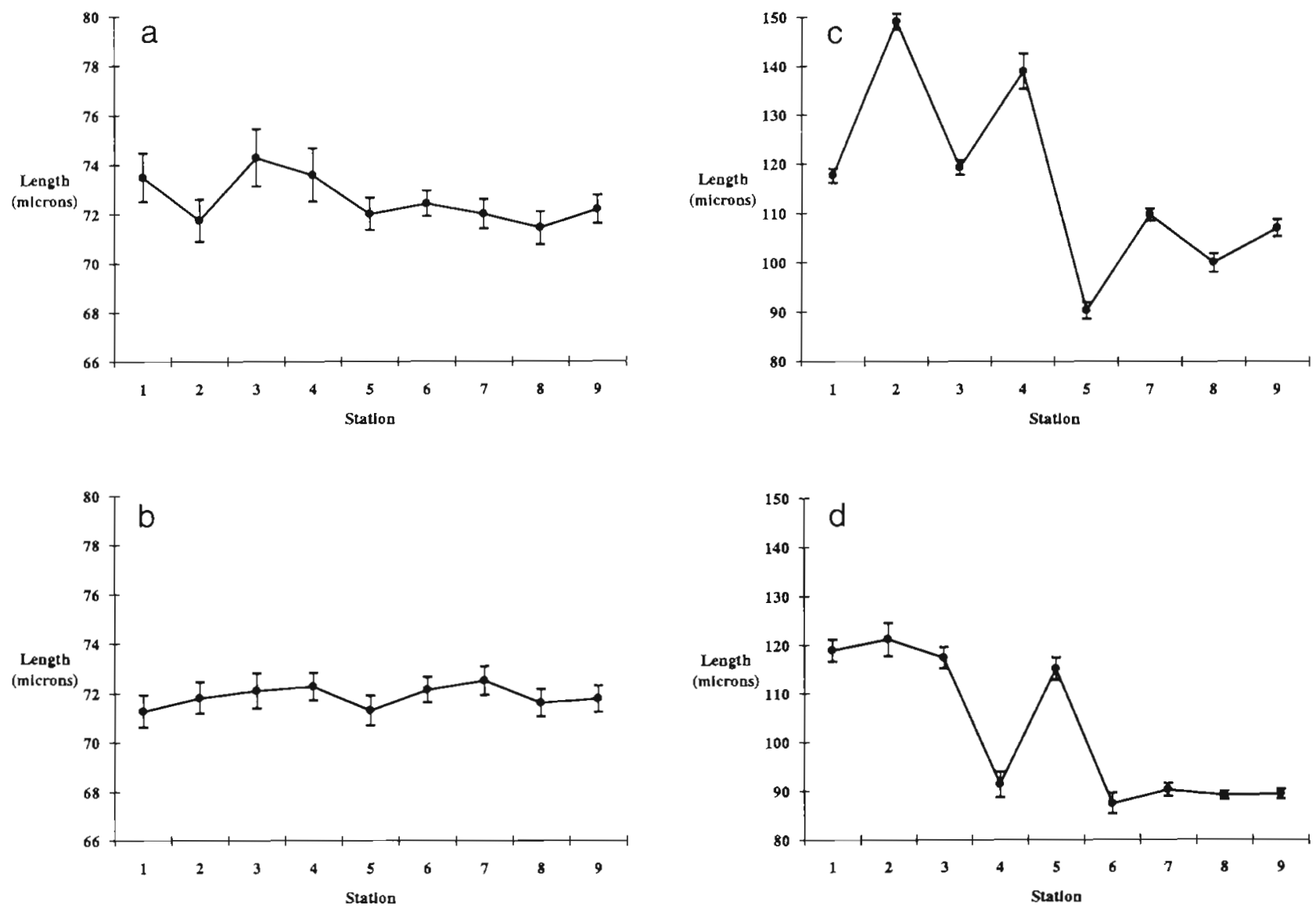

Fig. 4. Maximum shell length in $\mu \mathrm{m}$ (mean $\pm 2 \mathrm{SE}$ ). Mean based on total number of viable larvae from 2 replicate subsamples. (a) Crassostrea gigas $3.0 \mathrm{~m}$ subsurface water; (b) C. gigas sediment elutriate; (c) Tapes philippinarum $3.0 \mathrm{~m}$ subsurface water;

(d) T. philippinarum sediment elutriate

9 than the inshore Stns 1 to 5 . Oysters showed higher survival than clams at the inshore Stns 1 to 5 , for both bulk water and sediment elutriate samples (Fig. 3).

Survival of clam larvae in sediment elutriate samples from Stns $1 \& 2$ was lower than in bulk waters (Fig. 3c, d) but not at Stns 3 to 9 , with no differences between sample types for oysters (Fig. 3a, b).

Length. Oyster larvae were larger in the bulk water at Stns $1 \& 3$ (Fig. 4a, b) than in the sediment elutriate. There were no significant differences in lengths between stations or sample type for the remaining stations (Fig. 4a, b). Clam larvae exposed to bulk water (Fig. 4c) had greater shell lengths at Stns 1 to 4 than Stns 5 to 9 , with a similar trend in the sediment elutriate (Fig. 4d).

Clams exposed to bulk water from Stns $2,4,7,8 \& 9$ were considerably larger than the sediment elutriate samples, whilst larvae exposed to Stn 5 sediment elutriate had greater lengths than the bulk water (Fig. 4c, d). All surviving larvae measured in this study (Figs. 2 \& 4) had grown significantly from the initial thawed batch (Table 1) after the 48 h exposure period.

\section{DISCUSSION}

The embryonic stages of oyster larvae have been widely used to assess water quality in the past (Woelke 1972, Thain 1991). This early developmental stage is used routinely due to its convenience rather than for any preferred sensitivity or seasonal availability of the life stage. Developmental abnormalities from fertilised eggs to the prodissoconch (D-shell) larvae, often as high as $50 \%$ in controls, have been reported (Thain 1991, Utting \& Spencer 1991). Such high control abnormalities are probably congenitally derived (Bayne 1972 ) with no means of detecting this prior to the onset of the bioassay. However, by cryopreserving the Dshell (veliger) larvae from spawnings of a high developmental success, material is available indefinitely for bioassays. This technique reduces genetic heterogeneity between tests allowing bioassays to be conducted on siblings of identical age, over several seasons.

The aim of this investigation was to assess the biological effects on cryopreserved bivalve larvae, of various water samples along a known contaminant 
gradient in the North Sea. The results from the survival data (Figs. 1 \& 3) follow the published contaminant levels (Lohse 1990, Cofino et al. 1992, Hardy \& Cleary 1992) along the transect and demonstrate the effects of elevated contaminant levels in the surface microlayer and the sediment (Figs. 1 \& 3).

Clam larvae (Fig. 1c, d) were more sensitive to the microlayer sample than the oysters (Fig. 1a,b). Manahan \& Crisp (1982) studied the uptake of dissolved organic material (DOM) by veliger larvae, postulating that the velum (with its extensive surface area) was the site of DOM uptake, and not the digestive tract. Therefore, one possible explanation for the greater sensitivity of the relatively large clam larvae is that they would be expected to encounter more DOM and associated xenobiotics or toxic heavy metals (Hardy \& Cleary 1992) than the smaller oyster larvae.

Growth data (Figs. 2 \& 4) reflect natural levels of food abundance along the transect with phytoplankton numbers decreasing offshore (Thain 1992) and reduced larval growth at the corresponding stations. Larvae (Figs. 1 to 4 ) show a clear increase in growth with high mortality at Stns 1 to 5 and a reduced growth and accompanying high survival from Stns 6 to 9. This distinct bisection of the transect occurring between Stns 5 \& 6 correlates with the hydrographical data gathered on the cruise (Becker et al. 1992).

The present study confirms that cryopreserved bivalve larvae are indeed sensitive to environmentally realistic levels of contaminants and can be easily deployed at sea for field monitoring of water quality. The results obtained utilising 2 species of different ages highlights the need for multiple species testing if realistic biological effects are to be measured.

Acknowledgements. The support of this work is acknowledged to Cell Systems Ltd, Cambridge, by whom the author was employed during the workshop. Permission to publish was granted by the present owner of the technology, British Technology Group Ltd, London. Thanks are due to Dr A. R. D. Stebbing for the last-minute invitation to participate in the workshop and Dr L. Karbe and all my collegues of the Bremerhaven Workshop Water Quality Bioassay Group. My special thanks go to John Cleary and Mary Brinsley for provision of the microlayer samples as well as to Jan Bening and the captain and crew of RV 'Valdivia' (University of Hamburg) for logistical support.

\section{LITERATURE CITED}

Bayne, B. L. (1972). Some effects of stress in the adult on the larval development of Mytilus edulis. Nature 237: 459
Becker, G. A., Dick, S., Dippner, J. W. (1992). Hydrography of the German Bight. Mar. Ecol. Prog. Ser. 91: 9-18

Cofino, W. P., Smedes, F., de Jong, S. A., Abarnou, A., Boon, J. P., Oostingh, I., Davies, I. M., Klungsøyr, J., Wilhelmsen, S., Law, R. J., Whinnett, J. A., Schmidt, D., Wilson, S. (1992). The chemistry programme. Mar. Ecol. Prog. Ser $91: 47-56$

Connor, P. M. (1972). Acute loxicity of heavy metals to some marine larvae. Mar. Pollut Bull. 3: 190-192

Hardy, J. T., Cleary, J. (1992). Surface microlayer contamination and toxicity in the German Bight. Mar. Ecol. Prog. Ser. 91: $203-210$

Karbe, L. (1992). Toxicity of surface microlayer, subsurface water and sediment-elutriates from the German Bight summary and conclusions. Mar. Ecol. Prog. Ser. 91: $197-201$

Kobayashi, N. (1971). Fertilised sea urchin eggs as an indicatory material for marine pollution bioassay, preliminary experiments. Publs. Seto mar. Biol. Lab. 18: 379-406

Lohse, J. (1990). Distribution of organochlorine pollutants in North Sea sediments. International conference on North Sea Pollution - Technical Strategies for improvement. IAWPRC, EWPCA, NVA, Amsterdam, p. 227-236

Manahan, D. T., Crisp, D. J. (1982). The role of dissolved organic material in the nutrition of pelagic larvae: amino acid uptake by bivalve veligers. Am. Zool. 22: 635-646

Stebbing, A. R. D., Dethlefsen, V. (1992). Introduction to the Bremerhaven Workshop on Biological Effects of Contamination. Mar. Ecol. Prog. Ser. 91: 1-8

Stebbing, A. R. D. (1985). Bioassay. In: Bayne, B. L., Brown, D A., Burns, K., Dixon, D. R., Ivanovici, A., Livingstone, D. R., Lowe, D. M., Moore, M. N., Stebbing, A. R. D., Widdows, $J$. (eds.) The effects of stress and pollution on marine animals. Praeger, New York, p. 133-137

Stebbing, A. R. D., Pomroy, A. J. (1978). A sublethal technique for assessing the effects of contaminants using Hydra littoralis. Water Res. 12: 631-635

Thain, J. E. (1991). Biological effects of contaminants: oyster (Crassostrea gigas) embryo bioassay. ICES report. Techn. Mar. Environ. Sci. No. 11

Thain, J. E. (1992). Growth of the algae Isochrysis galbana and Tetraselmis suecica in water and sediment elutriate samples from the German Bight. Mar. Ecol. Prog. Ser. 91: $229-231$

Utting, S. D., McFadzen, I. R. B. (1990). Frozen larvae bivalve hatcheries could soon reap benefits. Fish Farmer 6: $45-47$

Utting, S. D., Spencer, B. E. (1991). The hatchery culture of bivalve mollusc larvae and juveniles. MAFF Directorate of Fisheries Research. Lowestoft Laboratory Leaflet. No. 68

Wilson, D. P. (1951). A biological difference between natura] sea waters. J. mar biol. Ass. U.K. 30: 1-22

Wilson, D. P., Armstrong, F. A. J. (1961). Biological differences between sea waters: Experiments in 1960. J. mar. biol. Ass. U.K. $41: 663-681$

Woelke, C. E. (1967). Measurement of water quality with the Pacific oyster embryo bioassay. Water Quality Criteria 416 : $112-120$

Woelke, C. E. (1972). Development of a receiving water quality bioassay criterion based on the 48 hour Pacific oyster (Crassostrea gigas) embryo. Washington Dept of Fisheries, Tech. Rep. 9: 1-93 